University of Nebraska - Lincoln

DigitalCommons@University of Nebraska - Lincoln

U.S. Environmental Protection Agency Papers

U.S. Environmental Protection Agency

2006

\title{
Assessing effects of alternative agricultural practices on wildlife habitat in lowa, USA
}

\author{
Mary Santelmann \\ Department of Geosciences, 104 Wilkinson Hall, Oregon State University, Corvallis, OR, 97331-5506, USA \\ Kathryn Freemark \\ National Wildlife Research Centre, Canadian Wildife Service, Environment Canada, Ottawa, Ont., Canada \\ $\mathrm{K} 1 \mathrm{AOH} 3$ \\ Jean Sifneos \\ Department of Geosciences, 104 Wilkinson Hall, Oregon State University, Corvallis, OR, 97331-5506, USA \\ Denis White \\ US Environmental Protection Agency, Corvallis, OR 97333, USA
}

Follow this and additional works at: https://digitalcommons.unl.edu/usepapapers

Part of the Civil and Environmental Engineering Commons

Santelmann, Mary; Freemark, Kathryn; Sifneos, Jean; and White, Denis, "Assessing effects of alternative agricultural practices on wildlife habitat in lowa, USA" (2006). U.S. Environmental Protection Agency Papers. 22.

https://digitalcommons.unl.edu/usepapapers/22

This Article is brought to you for free and open access by the U.S. Environmental Protection Agency at DigitalCommons@University of Nebraska - Lincoln. It has been accepted for inclusion in U.S. Environmental Protection Agency Papers by an authorized administrator of DigitalCommons@University of Nebraska - Lincoln. 


\title{
Assessing effects of alternative agricultural practices on wildlife habitat in Iowa, USA
}

\author{
Mary Santelmann ${ }^{\mathrm{a}, *}$, Kathryn Freemark $^{\mathrm{b}, 1}$, Jean Sifneos $^{\mathrm{a}}$, Denis White ${ }^{\mathrm{c}}$ \\ ${ }^{a}$ Department of Geosciences, 104 Wilkinson Hall, Oregon State University, Corvallis, OR, 97331-5506, USA \\ ${ }^{\mathrm{b}}$ National Wildlife Research Centre, Canadian Wildife Service, Environment Canada, Ottawa, Ont., Canada K1A OH3 \\ ${ }^{\mathrm{c}}$ US Environmental Protection Agency, Corvallis, OR 97333, USA
}

Received 27 January 2004; received in revised form 7 September 2005; accepted 28 September 2005

Available online 5 December 2005

\begin{abstract}
A habitat-change model was used to compare past, present, and future land cover and management practices to assess potential impacts of alternative agricultural practices on wildlife in two agricultural watersheds, Walnut Creek and Buck Creek, in central Iowa, USA. This approach required a habitat map for each scenario based on soil type and land cover, a list of resident species, and an estimate of the suitability of each of 26 habitat classes for every species. Impact on wildlife was calculated from median percent change in habitat area relative to the present. Habitat classes with the highest species richness for native vertebrates were ungrazed riparian forest, upland forest and wet prairie. Differences in habitat composition and configuration were evident among maps of the watersheds for the past, present, and three alternative future scenarios (Production, Water Quality, and Biodiversity). The Production scenario ranked lowest in providing habitat for all native taxa. For most taxa, changes in wildlife habitat due to land use changes in the Biodiversity, Water Quality, and Past scenarios were similar, resulting in greater habitat than either the present landscape or the Production scenario. For native birds, amphibians, mammals, and rare species in both watersheds, the Biodiversity scenario ranked highest in providing habitat, and the Water Quality scenario was similar to or slightly below the Biodiversity scenario. The Water Quality scenario was similar to or slightly better than the Biodiversity scenario for reptiles and butterflies in both watersheds, and both ranked higher than the Production scenario for these taxa.
\end{abstract}

(C) 2005 Elsevier B.V. All rights reserved.

Keywords: Future scenarios; Iowa watersheds; Landscape change; Wildlife habitat; Butterflies

\section{Introduction}

To address concerns about environmental and ecological degradation from modern agriculture (Freemark, 1995; Krebs et al., 1999; Tilman et al., 2001) a shared vision of landscape design and management alternatives is needed (Meadows, 1996; Runge, 1997; Ahern, 1999). Planners and policymakers need better tools for understanding landscapelevel effects of planning and policy. A relatively recent innovation that addresses these needs is the use of scenario-

\footnotetext{
* Corresponding author. Tel.: +1 541737 1215; fax: +1 5417371200 .

E-mail address: santelmm@ @cience.oregonstate.edu (M. Santelmann).

${ }^{1}$ Current address: National Indicators \& Reporting Office, Knowledge Integration Directorate, Environment Canada, Gatineau, Qué., Canada K1A OH3.
}

based alternative futures, made feasible by advances in landscape ecology, landscape design, geographic information systems, and computer modelling of ecological and economic processes. Consideration of the alternative futures that emerge from different scenarios can help decisionmakers and stakeholders envision and evaluate choices in a way specific to place and time (Costanza, 2000; Nassauer et al., 2002; Steinitz et al., 2003; Baker et al., 2004; Santelmann et al., 2004).

A collaborative, interdisciplinary study applying a scenario-based alternative futures approach was initiated in 1996 for two watersheds in central Iowa to design and evaluate alternative future scenarios that might result from different priorities for agricultural production, native biodiversity, water quality, social and economic considerations (Santelmann et al., 2001; Nassauer et al., 2002; 
Nassauer and Corry, 2004). The research described here is one of several modelling approaches (Coiner et al., 2001; Vaché et al., 2002; Rustigian et al., 2003; Santelmann et al., 2004) used to evaluate potential impacts of habitat change on wildlife. In addition, a reconstructed presettlement landscape was evaluated to provide a historical perspective on changes in habitat for native species in the study watersheds.

The response of native plant and animal species to changes in land cover and management practices may be among the most sensitive indicators of ecosystem response, and thus is considered a valuable indicator in ecosystem risk assessments (Pratt and Cairns, 1992; White et al., 1999). The approach described here, modified from White et al. (1997), is based on the premise that impact on a species increases as its habitat is depleted or degraded. It requires a habitat map for each scenario, a list of resident species, and an estimate of the suitability of each habitat for each species. Impact on wildlife habitat is calculated for a set of species as the median percent change in habitat for that set of species relative to the present. Life history requirements of species (e.g., minimum area requirements) can be incorporated but were not employed here.

\section{Methods}

Two watersheds (Fig. 1) were studied, Walnut Creek in Boone and Story Counties (5130 ha) in the Des Moines Lobe Region and Buck Creek watershed, Poweshiek County (8820 ha) on the Southern Iowa Drift Plain. The Des Moines Lobe is relatively flat with rich, productive soils, corn and soybeans covering more than $80 \%$ of the land area. The Southern Iowa Drift Plain has a rolling topography and more varied land cover (Prior, 1991). The Walnut Creek watershed was once dominated by prairie, dotted with prairie pothole wetlands, most of which have now been drained for row crops (Hewes, 1951). The Buck Creek watershed was located on an older, glaciated surface with well-drained soils. Its hills and valleys provided firebreaks that allowed the growth of more extensive riparian forest, particularly in the southern end of the watershed.

Present land cover for the Buck Creek and Walnut Creek watersheds (hereafter termed the present) was digitized from 1:20,000 aerial photographs taken in 1990, and groundtruthed in 1993-1994 (Freemark, 1995; Bergin et al., 2000) at a spatial resolution of three meters. With respect to current agricultural set-aside programs, $16 \%$ of the land area in the Buck Creek watershed was enrolled in the Conservation Reserve Program (CRP) in 1994. Walnut Creek had no CRP land enrolled in 1994.

\subsection{Scenarios evaluated}

An iterative, interdisciplinary, GIS-based process was used to develop and map three future scenarios for both (a)

(b) Buck Creek

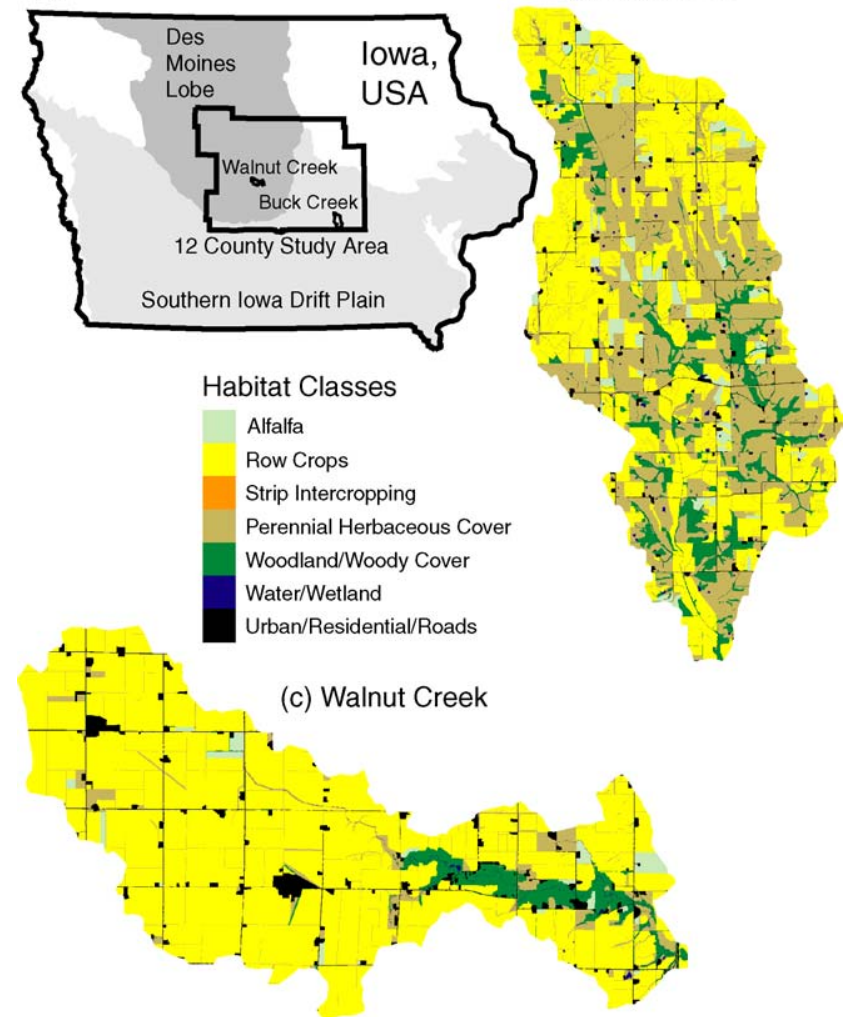

Fig. 1. (a) Location of Buck and Walnut Creek watersheds in Iowa, USA, and present habitat cover (ca. 1994) for (b) Buck Creek watershed (8820 ha) and (c) Walnut Creek watershed (5130 ha). Habitat classes were combined from 26 to 7 for visualization (Table 1 shows how map classes in the figures correspond to the various habitat classes).

watersheds (Nassauer et al., 2002; Nassauer and Corry, 2004) that could result in 2025 from different sets of policy choices.

The Production scenario (a) is perceived as the future most likely to emerge if profitable agricultural production remains the dominant objective of landscape management (Figs. 2a and 3a). In this scenario, more land is converted to cultivation, woodlands have nearly disappeared, riparian areas have narrow (3-6 m) grass buffers, corn and soybeans are grown with limited crop rotations, and there is little land area in pasture or alfalfa.

The Water Quality scenario (b) assumes that land cover patterns in both watersheds (Figs. $2 b$ and $3 b$ ) have evolved as landowners strive to meet water quality standards. In this scenario, woodlands have been maintained, riparian buffers have been widened from 3-6 to 15-60 m, small wetlands have been created to process flow from tile drains, and substantial areas are in pasture and alfalfa production.

The Biodiversity scenario (c) is based on the assumption that land cover patterns have changed to increase habitat for indigenous wildlife. In this scenario, at least 260 ha of each watershed have been set aside in permanent, indigenous ecosystem core reserves. The reserve in Buck Creek is a 


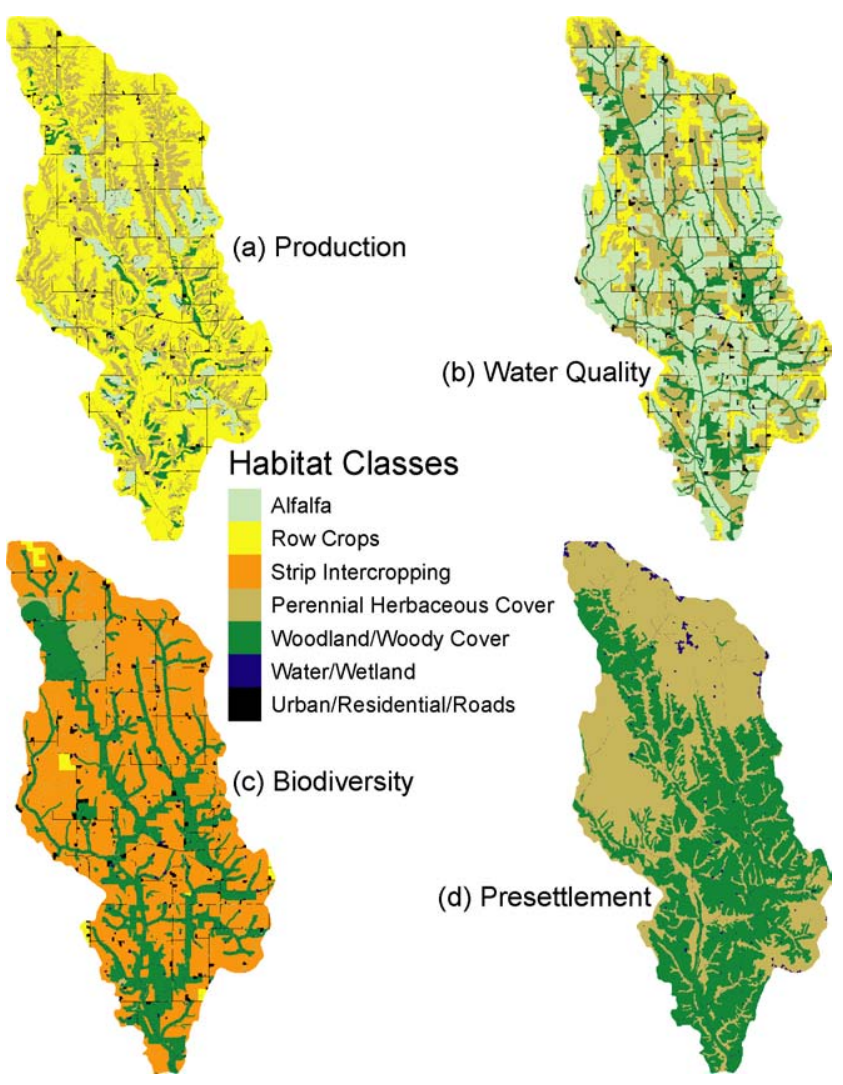

Fig. 2. Map of alternative futures and the presettlement past for Buck Creek watershed. Habitat classes as in Fig. 1.

mosaic of prairie, savanna and forest (Fig. 2c), whereas reserves in Walnut Creek consist of a large prairie-wetland complex in the western portion of the watershed and a riparian forest reserve along the creek (Fig. 3c). Riparian areas are 30-90 m wide, agroforestry and strip intercropping have developed, in which native perennial species are interspersed with corn and soybeans.

The presettlement scenario reflected the land cover of the early 1800 s, and was drawn from the Iowa Soil Properties and Interpretations Database (ISPAID; http://www.ia.nrcs.usda.gov/soils/icss_data.html) based on soil attributes (cf. Galatowitsch and van der Valk, 1994).

\subsection{Species-habitat associations}

The wildlife species considered were all bird, mammal, reptile, amphibian, and butterfly species currently recorded in central Iowa or likely to be reintroduced or to expand their current ranges into central Iowa (Jackson et al., 1996; Kent and Dinsmore, 1986).

Twenty-six wildlife habitat classes (Table 1 and Appendix A) were derived from land cover classes primarily by reviewing bird species' use of habitats (Best et al., 1995) and evaluating potential differences for other vertebrates. A matrix of species-habitat associations, ranking habitat suitability for each species in each potential habitat type was then generated through review of the literature and

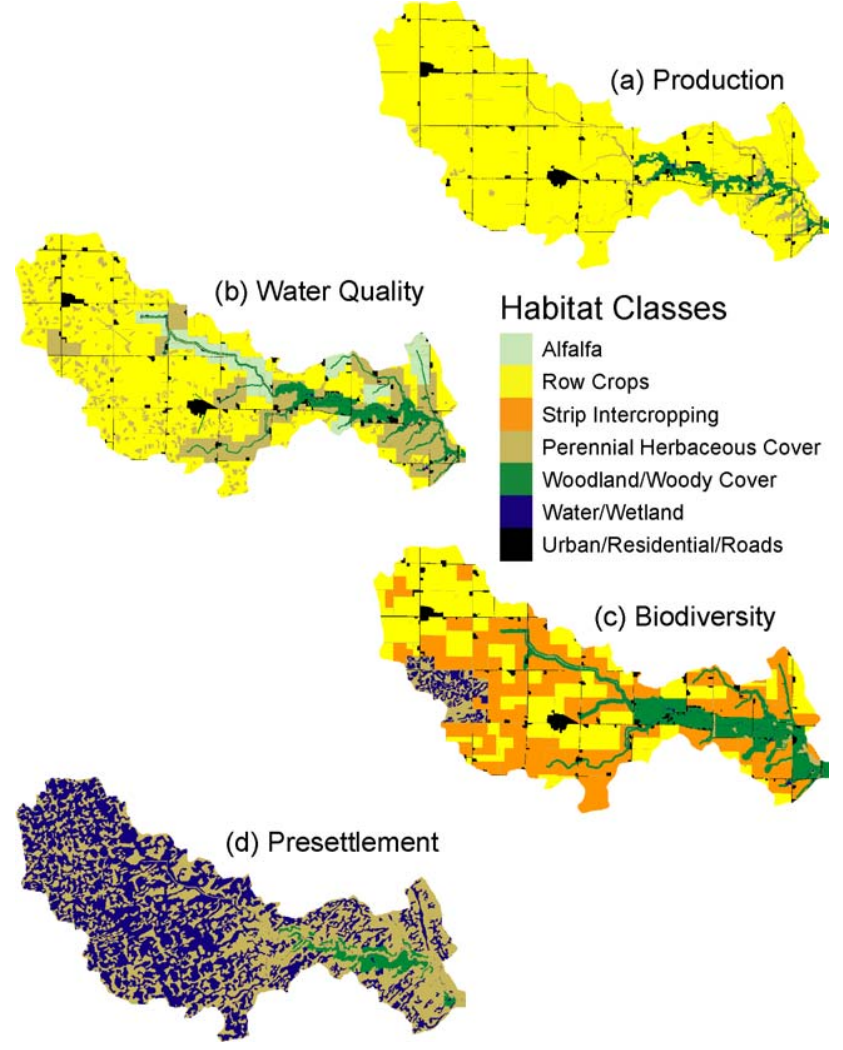

Fig. 3. Map of alternative futures and the presettlement past for the Walnut Creek watershed. Habitat classes as in Fig. 1.

expert judgment. Eight introduced and 239 native vertebrate species (146 birds, 52 mammals, 29 reptiles, 12 amphibians), and 117 butterfly species were included. Ungrazed riparian and upland forest had the highest species richness, with 171 and 140 species, respectively. Few vertebrate species were unique to any single habitat type, semipermanent wetland and ungrazed riparian forest having the most unique species (five and four, respectively).

For groups other than birds, a $0-4$ point scale was used, as follows: $0=$ habitat not used by the species; $1=\operatorname{sink}$ or marginal habitat of the lowest quality; $2=$ sink or marginal habitat of a quality that can maintain a population for short periods of time; $3=$ source habitat capable of supporting individuals during the life-stages that are most critical for sustaining populations for long periods of time; $4=$ optimal habitat in which the species has the highest reproduction and/or survival, capable of sustaining populations indefinitely.

For birds, habitat associations were assigned from the literature (Best et al., 1995, 2001; Freemark et al., 1991; Jackson et al., 1996; Kent and Dinsmore, 1986; Stallman and Best, 1996; Lokemoen and Beiser, 1997), and by expert opinion. Habitat suitability scores for birds were initially based on the 0-5 point abundance scale used by Best et al. (1995), adjusted to increase value of habitat used for nesting by one point, then weighted to correspond to the $0-4$ point scale used for the other taxa. For mammals, habitat affinities 
Table 1

Number of species in various categories ${ }^{\mathrm{a}}$ for the 26 habitat classes ${ }^{\mathrm{b}}$. The seven land cover classes mapped in Figs. 1-3 are shown in column 2 , and the average suitability score for each habitat class, averaged over all native vertebrate species (av. suit), in column 5

\begin{tabular}{|c|c|c|c|c|c|c|c|c|c|c|c|}
\hline \multirow[t]{2}{*}{ Code } & \multirow[t]{2}{*}{ Map class } & \multirow[t]{2}{*}{ Habitat } & \multicolumn{9}{|c|}{ Vertebrate species categories } \\
\hline & & & native & av.suit & amph & rept & mamm & bird & intro & s1s2 & Leps \\
\hline 1 & 2 & rc.cp & 91 & 0.66 & 0 & 16 & 24 & 51 & 7 & 5 & 10 \\
\hline 2 & 2 & rc.ct & 103 & 0.9 & 0 & 16 & 36 & 51 & 7 & 7 & 10 \\
\hline 3 & 3 & rc.ns & 122 & 1.19 & 0 & 16 & 44 & 62 & 7 & 12 & 16 \\
\hline 4 & 4 & rc.sg & 69 & 0.58 & 0 & 16 & 24 & 29 & 7 & 7 & 2 \\
\hline 5 & 4 & rc.fall & 61 & 0.67 & 0 & 16 & 41 & 4 & 3 & 7 & 1 \\
\hline 6 & 3 & rc.os & 115 & 1.25 & 0 & 16 & 42 & 57 & 7 & 11 & 12 \\
\hline 7 & 2 & rc.o & 92 & 0.79 & 0 & 16 & 23 & 53 & 7 & 7 & 11 \\
\hline 8 & 7 & farmstead & 110 & 1.36 & 0 & 20 & 36 & 54 & 7 & 8 & 40 \\
\hline 9 & 4 & strip.h & 115 & 1.47 & 0 & 25 & 45 & 45 & 6 & 11 & 21 \\
\hline 10 & 5 & strip.w & 113 & 1.6 & 0 & 23 & 37 & 53 & 4 & 10 & 10 \\
\hline 11 & 4 & grass.crp & 117 & 1.53 & 0 & 26 & 44 & 47 & 5 & 16 & 57 \\
\hline 12 & 1 & grass.hay & 112 & 1.11 & 0 & 27 & 40 & 45 & 5 & 16 & 39 \\
\hline 13 & 4 & grass.pd & 115 & 1.55 & 0 & 27 & 45 & 43 & 5 & 18 & 81 \\
\hline 14 & 6 & grass.pw & 128 & 1.91 & 10 & 26 & 43 & 49 & 5 & 16 & 76 \\
\hline 15 & 4 & shrub.past & 127 & 1.4 & 2 & 27 & 44 & 54 & 6 & 16 & 53 \\
\hline 16 & 4 & shrub.ung & 128 & 1.71 & 2 & 27 & 43 & 56 & 5 & 11 & 55 \\
\hline 17 & 5 & for. 50 & 125 & 1.68 & 0 & 27 & 33 & 65 & 4 & 8 & 36 \\
\hline 18 & 5 & for.rug & 171 & 2.29 & 7 & 27 & 34 & 103 & 3 & 12 & 40 \\
\hline 19 & 5 & for.upug & 140 & 1.86 & 0 & 26 & 32 & 82 & 3 & 8 & 35 \\
\hline 20 & 5 & for.upg & 125 & 1.56 & 0 & 26 & 32 & 67 & 3 & 8 & 27 \\
\hline 21 & 5 & for.sug & 100 & 1.39 & 0 & 27 & 47 & 26 & 3 & 11 & 64 \\
\hline 22 & 5 & for.sg & 94 & 1.14 & 0 & 27 & 42 & 25 & 3 & 12 & 64 \\
\hline 23 & 6 & wet.sp & 111 & 1.5 & 12 & 26 & 11 & 62 & 2 & 10 & 26 \\
\hline 24 & 6 & wet.pond & 92 & 1.39 & 12 & 27 & 13 & 40 & 0 & 9 & 14 \\
\hline 25 & 6 & wet.st & 63 & 1.05 & 7 & 28 & 13 & 15 & 0 & 8 & 33 \\
\hline 26 & 6 & wet.eng & 90 & 1.11 & 8 & 26 & 12 & 44 & 0 & 6 & 24 \\
\hline Total & & & 239 & na & 12 & 29 & 52 & 146 & 8 & 24 & 117 \\
\hline
\end{tabular}

${ }^{\text {a }}$ native: all native vertebrates, amph: amphibians, rept: reptiles, mamm: mammals, bird: birds, intro: introduced, S1S2: threatened and endangered, Leps: butterflies.

b Key to habitat classes: rc.cp: row crop chisel plow, rc.ct: row crop conservation tillage, rc.ns: row crop native strip, rc.sg: small grains, rc.fall: fallow, rc.os: row crop organic strip, rc.o: row crop organic, farmstead, strip.h: herbaceous strip, strip.w: woody strip, grass.crp: Conservation Reserve Program, grass.hay: alfalfa/hay, grass.pd: dry prairie, grass.pw: wet prairie, shrub.past: pasture, shrub.ung: ungrazed shrubland, for.50: ungrazed forest less than 50 years old, for.rug: ungrazed riparian forest, for.upug: ungrazed upland forest, for.upg: grazed upland forest, for.sug: ungrazed savanna, for.sg: grazed savanna, wet.sp: semipermanent wetland, wet.pond: pond, wet.st: stream, and wet.eng: engineered wetland.

were gathered from the literature (Baker, 1983; Caire et al., 1989; Clark and Young, 1986; Hayslett and Danielson, 1994; Kurta, 1995; Schwartz and Schwartz, 1981; Snyder and Best, 1988; Stallman and Best, 1996) and those scored as most suitable were those in which individuals of the species were known to reproduce and spend the majority their time. A species-habitat association matrix was constructed for reptiles and amphibians based on the published literature for the Midwest (Smith, 1961; Minton, 1972; Vogt, 1981; Christiansen and Bailey, 1991; Collins, 1993; Oldfield and Moriarty, 1994; Casper, 1996; Harding, 1997) and expert judgment. For butterflies, the species-habitat association matrix was constructed by a local expert with reference to Scott (1986). The complete species-habitat association matrix is available from the authors.

Habitat associations were used to prepare a habitat map for each species in the past, present and each future scenario. Each map consisted of the score for a species in the habitat at each pixel location. From these maps of habitat scores the total amount of habitat for a species in a landscape was estimated as the sum of all the scores across the landscape. The percentage change in habitat for each species relative to the present was then calculated for the three future scenarios and for the past. Finally, the median of the percentage changes for different groups of species was used as a summary statistic, following the statistical approach to measuring habitat change developed in White et al. (1997).

The formula used for calculating the habitat change score, $\mathrm{HC}_{j}$, for a specific group of species for one of the future landscapes, or for the past landscape, was:

$\mathrm{HC}_{j}=\operatorname{median}\left(\sum_{i}^{\text {species }} \frac{\text { hab }_{i, j}-\text { hab }_{i, \text { present }}}{\text { hab }_{i, \text { present }}} \times 100\right)$,

for a future or past landscape, $j$, hab $b_{i, j}$ being the suitabilityweighted abundance of species $i$ in the future or past landscape $j$, and hab ${ }_{i \text {,present }}$ the suitability-weighted abundance of species $i$ in the present landscape. Positive values of the 
median percent change statistic meant that more habitat for the species occurred in the watershed in the future or past landscape than in the present, and negative values the reverse.

\subsection{Data analysis}

For analysis, species were grouped into native birds, mammals, reptiles, amphibians and butterflies, all native vertebrates, all introduced vertebrates, and all rare vertebrates. The rare vertebrates were defined as those species with state conservation ranks of rare and vulnerable, as determined by the Iowa Natural Areas Inventory (http:// www.state.ia.us/dnr/organiza/ppd/nai.htm).

To investigate the effects on the habitat change statistics of possible errors in the species-habitat suitability scores, a Monte Carlo simulation study was conducted. The suitability scores were altered under an assumed error model and variability in the results computed. Scores were assumed to have errors that could be represented by a normal distribution with a mean of 0 and a standard deviation of an integral number of score levels.

A modified species-habitat suitability matrix was generated containing a modified suitability score for each species in each habitat. The modified scores were generated by combining a term generated from the error model with the original scores. If the resulting score was less than 0 it was set to 0 ; if greater than the maximum score it was set to the maximum score. Scores originally set to 0 were maintained at 0 and not altered. A species could thus change from present to absent if the score became 0 , but could never change from absent to present. Errors were generated in this way and the habitat statistics were calculated for each taxonomic group as well as introduced and rare vertebrate species subsets. The error generation process was repeated 1000 times and the mean and standard deviation of the median statistics were calculated.

\section{Results}

Differences between scenarios in habitat composition and configuration were evident between Buck and Walnut Creek watersheds, as well as between the reconstructed past and the alternative futures (Figs. 2 and 3). More of Walnut Creek was cropped in all future scenarios compared to Buck Creek, consistent with current agricultural practices and land capability. Cropping was most extensive in both watersheds under the Production scenario, and row crops were exclusively corn and soybeans. Because of its topography and highly erodible soils, most of Buck Creek was in perennial herbaceous cover under the Water Quality scenario in contrast to Walnut Creek. Bioreserves in the Biodiversity scenario were restored to upland woodland, savanna, and prairie in Buck Creek; and to prairie pothole wetlands interspersed with upland prairie, and a riparian woodland reserve in Walnut Creek. Strip intercropping was extensive in both watersheds under the Biodiversity scenario, and woodland and woody cover were more extensive compared to the present.

\subsection{Habitat changes}

Changes in habitat area relative to the present for butterflies and for vertebrates by taxon (Fig. 4) and for vertebrates by species of concern (Fig. 5) varied between watersheds and among scenarios (Table 2). Variability in median percent change in habitat area was generally less than $20 \%$ ( \pm 1 S.D.) except for amphibians and introduced species, which were more variable owing to the small number of species involved (Table 3 ).

All native taxa (Fig. 4a) had more habitat in the past relative to the present in Buck Creek (27 \pm 8 to $164 \pm 17 \%$ ). In Walnut Creek (Figs. 4b and 5b), native vertebrates overall and most taxa (particularly amphibians and butterflies) had more habitat in the past relative to the present ( $34 \pm 10$ to $11529 \pm 1425 \%)$. Native bird species not associated with
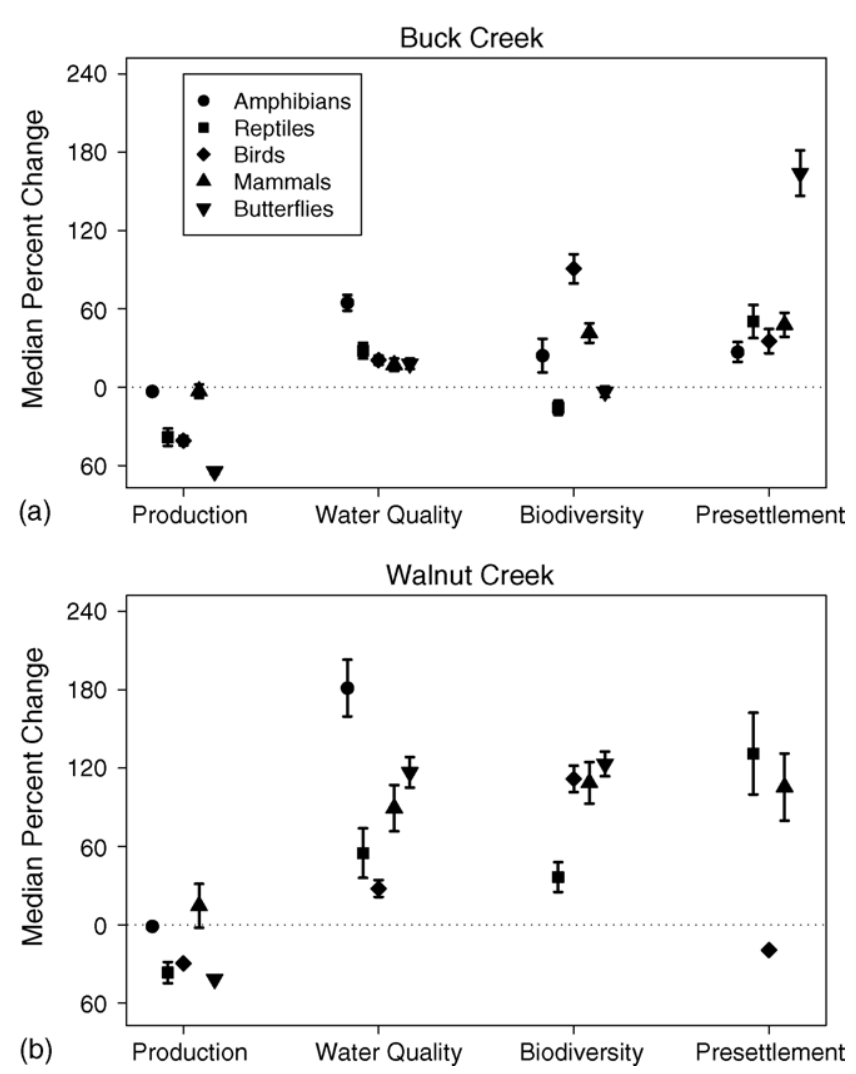

Fig. 4. Median percent change ( \pm 1 S.D.) in habitat area (adjusted by suitability), compared to the present, for taxa of native species (excluding introduced, extinct and extirpated species) and butterflies, for (a) Buck Creek watershed and (b) Walnut Creek watershed. Values $>0$ indicate habitat gain compared to the present; values $<0$ indicate habitat loss compared to the present. Species groups with changes greater than $200 \%$ are not shown (Walnut Creek amphibians in Biodiversity and Presettlement, and butterflies in Presettlement). See Table 3 for values. 

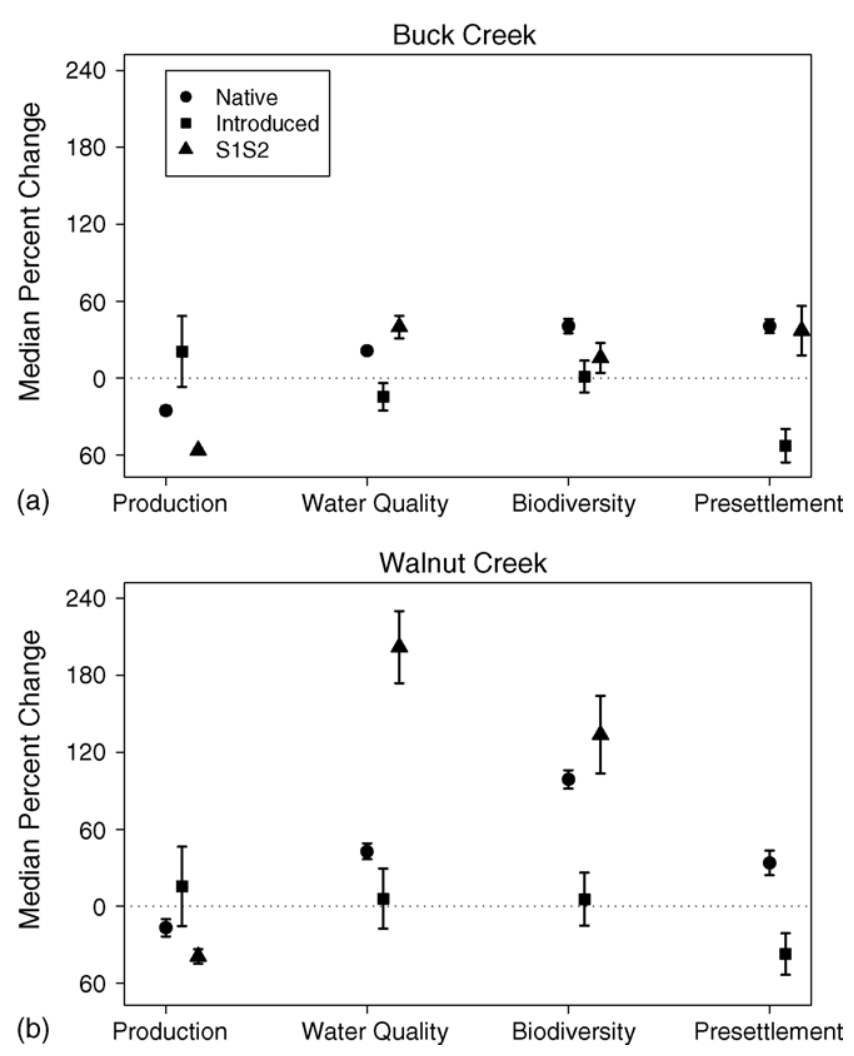

Fig. 5. Median percent change ( \pm 1 S.D.) in habitat area (adjusted by suitability), compared to the present, for all native vertebrate species, introduced vertebrate species, and rare $(\mathrm{S} 1-\mathrm{S} 2)$ vertebrate species for both watersheds. Values $>0$ indicate habitat gain compared to the present; values $<0$ indicate habitat loss compared to the present. Results for S1-S2 species for Presettlement in Walnut Creek not shown because values were greater than $200 \%$ ( $723.9 \%$, see Table 3 for values).

wetland habitat had less habitat in the past relative to the present $(-19 \pm 0.1 \%)$. Also, the change statistic does not include species associated only with ephemeral or semipermanent wetlands, since such species have no habitat in the present. However, wetland-associated species would have had extensive habitat in the Walnut Creek watershed in the past. Studies by Rustigian et al. (2003) indicate that the presence of prairie pothole wetlands greatly increased modelled population sizes for amphibian species in Walnut Creek watershed. Introduced species had less habitat in the past relative to the present in both watersheds, whereas rare species had more habitat in the past relative to the present, particularly in Walnut Creek watershed (Fig. 5).

In the Production scenario, all taxa (Fig. 4) and native vertebrates overall (Fig. 5) lost habitat in both watersheds $(-1 \pm 0.2$ to $-65 \pm 2 \%)$ except mammals, for which habitat remained stable because conservation tillage in row crops provided more cover to small mammals than conventional-till practices. Habitat for introduced species remained about the same while rare species lose habitat in both watersheds in this scenario.

In the Water Quality scenario, all taxa (Fig. 4) and native vertebrates overall (Fig. 5) had more habitat in both Buck
Creek $(17 \pm 5$ to $65 \pm 6 \%)$ and Walnut Creek $(28 \pm 7$ to $181 \pm 22 \%$ ) relative to the present (Fig. 4). Introduced species lost habitat in Buck Creek watershed but remained about the same in Walnut Creek watershed, while rare species gained habitat in both (Fig. 5).

In the Biodiversity scenario, all taxa (Fig. 4) and native vertebrates overall (Fig. 5) had more habitat in Walnut Creek ( $37 \pm 11$ to $1617 \pm 128 \%$ ), and in Buck Creek ( $24 \pm 13$ to $91 \pm 11 \%)$, except for reptiles $(-16 \pm 5 \%)$ and butterflies $(-4 \pm 4)$ in the latter. The conversion of pasture, alfalfa, and CRP to strip intercropping appeared to be responsible for the decline in habitat area for reptile species in this scenario for Buck Creek (Table 1). Alfalfa, pasture, and CRP were assigned as habitat for 27,27 , and 26 reptile species, respectively, strip intercropping for only 16 reptile species (Table 1). Similarly, more butterfly species were associated with alfalfa, pasture, and CRP (39, 53, and 57 species, respectively) than with strip intercropping (16 species). Habitat for introduced species remained about the same while rare species gain habitat in both watersheds (Fig. 5).

For most taxa, estimated changes in wildlife habitat under the Biodiversity and Water Quality scenarios were similar to each other and to those for the reconstructed past, and indicated greater habitat than the present landscape or the Production scenario. For native vertebrates overall, birds, amphibians, and rare species in both watersheds the Biodiversity scenario ranked highest in providing habitat, followed by the Water Quality scenario and the Production scenario. For mammals in Walnut Creek watershed, the Water Quality and Biodiversity scenarios were equivalent, and both ranked higher than the Production scenario. For reptiles and butterflies in both watersheds, the Water Quality scenario was similar to or slightly better than the Biodiversity scenario, and both ranked higher than the Production scenario. Future scenarios were generally similar to the present with respect to habitat area for introduced species.

\subsection{Species richness changes}

The existing landscape showed "hotspots" for species richness of native vertebrates in the riparian forests and perennial herbaceous cover and "coldspots" in row crops (Table 1). Effects of habitat changes on native vertebrates between the past and future scenarios compared to the present were evident in terms of species richness for both watersheds. Presettlement habitat in each watershed supported higher species richness over more area than in the present. The difference in species richness was largely due to the difference between the species richness of row crops as compared to wet and dry prairie in Walnut Creek and to dry prairie and upland forest in Buck Creek (Table 2). Species richness was lower in the past compared to the present in areas which had been dry prairie in the past but were converted to pasture and ungrazed upland woodland in the present. 
Table 2

Habitat conversions (in \% of watershed area) from the present to each alternative future or past scenario (P: Production, WQ: Water Quality, B: Biodiversity, and PS: Past) and effect on species richness of native vertebrates for Buck Creek and Walnut Creek

\begin{tabular}{|c|c|c|c|c|c|}
\hline Scenario & Habitat type in the present & Habitat type in future or past & Area $(\%)$ Buck Cr. & Area (\%) Walnut Cr. & Number of species \\
\hline $\bar{P}$ & Upland ungrazed & Row crop conservation till & 3.78 & 1.16 & -37 \\
\hline $\mathrm{P}$ & Pasture & Row crop conservation till & 10.77 & 2.21 & -24 \\
\hline$P$ & Pasture & Alfalfa/hay & 2.59 & na & -15 \\
\hline $\mathrm{P}$ & Crp & Row crop conservation till & 12.68 & na & -14 \\
\hline $\mathrm{P}$ & Crp & Alfalfa/hay & 2.86 & na & -5 \\
\hline $\mathrm{P}$ & Herbaceous & Row crop conservation till & 1.98 & 1.57 & -12 \\
\hline $\mathrm{P}$ & Alfalfa/hay & Row crop conservation till & 7.96 & 2.52 & -9 \\
\hline $\mathrm{P}$ & Farmstead and urban & Row crop conservation till & na & 1.27 & -7 \\
\hline $\mathrm{P}$ & Row crop chisel plow & Row crop conservation till & 42.86 & 80.75 & 12 \\
\hline WQ & Upland ungrazed & Upland grazed & 5.56 & 2.35 & -15 \\
\hline WQ & Row crop chisel plow & Row crop conservation till & 10.79 & 53.61 & 12 \\
\hline WQ & Alfalfa/hay & Pasture & 3.49 & 1.14 & 15 \\
\hline WQ & Row crop chisel plow & Alfalfa/hay & 22.89 & 7.26 & 21 \\
\hline WQ & Row crop chisel plow & Crp & 3.27 & 5.71 & 26 \\
\hline WQ & Row crop chisel plow & Pasture & 3.26 & 12.88 & 36 \\
\hline WQ & Row crop chisel plow & Herbaceous & 1.16 & na & 24 \\
\hline WQ & Pasture & Alfalfa/hay & 1.67 & na & -15 \\
\hline WQ & Savanna ungrazed & Savanna grazed & 1.05 & na & -6 \\
\hline WQ & Crp & Alfalfa/hay & 11.54 & na & -5 \\
\hline WQ & Crp & Pasture & 2.08 & na & 10 \\
\hline WQ & Herbaceous & Alfalfa/hay & 1.18 & na & -3 \\
\hline WQ & Pasture & Riparian ungrazed & 1.21 & na & 44 \\
\hline WQ & Row crop chisel plow & Riparian ungrazed & 1.55 & na & 80 \\
\hline $\mathrm{B}$ & Row crop chisel plow & Row crop conservation till & na & 32.14 & 12 \\
\hline $\mathrm{B}$ & Row crop chisel plow & Organic strip & na & 2.73 & 24 \\
\hline $\mathrm{B}$ & Row crop chisel plow & Prairie dry & na & 1.47 & 24 \\
\hline B & Row crop chisel plow & Row crop native strip & 34.95 & 35.07 & 31 \\
\hline $\mathrm{B}$ & Row crop chisel plow & Upland grazed & 1.25 & 1.8 & 34 \\
\hline $\mathrm{B}$ & Row crop chisel plow & Prairie wet & na & 3.02 & 37 \\
\hline B & Row crop chisel plow & Riparian ungrazed & 4.88 & 3.36 & 80 \\
\hline $\mathrm{B}$ & Pasture & Prairie dry & 1.41 & na & -12 \\
\hline B & Pasture & Row crop native strip & 7.74 & na & -5 \\
\hline $\mathrm{B}$ & Pasture & Upland grazed & 1.08 & na & -2 \\
\hline $\mathrm{B}$ & Pasture & Riparian ungrazed & 2.64 & na & 44 \\
\hline $\mathrm{B}$ & Crp & Row crop native strip & 10.91 & na & 5 \\
\hline B & Crp & Upland grazed & 1.04 & na & 8 \\
\hline B & Crp & Riparian ungrazed & 2.77 & na & 54 \\
\hline B & Herbaceous & Row crop native strip & 1.41 & na & 7 \\
\hline $\mathrm{B}$ & Alfalfa/hay & Row crop native strip & 6.48 & na & 10 \\
\hline PS & Upland ungrazed & Prairie dry & 1.74 & 1.62 & -25 \\
\hline PS & Pasture & Prairie dry & 5.32 & 1.68 & -12 \\
\hline PS & Crp & Prairie dry & 5.29 & na & -2 \\
\hline PS & Alfalfa/hay & Prairie dry & 3.61 & 1.51 & 3 \\
\hline PS & Farmstead and urban & Prairie dry & na & 2.17 & 5 \\
\hline PS & Herbaceous & Prairie wet & na & 1.46 & 13 \\
\hline PS & Pasture & Upland ungrazed & 8.31 & na & 13 \\
\hline PS & Crp & Upland ungrazed & 10.63 & na & 23 \\
\hline PS & Alfalfa/hay & Upland ungrazed & 5.32 & na & 28 \\
\hline PS & Herbaceous & Upland ungrazed & 1.39 & na & 25 \\
\hline PS & Row crop chisel plow & Upland ungrazed & 12.23 & na & 49 \\
\hline PS & Row crop chisel plow & Semi permanent wetland & na & 3.34 & 20 \\
\hline PS & Row crop chisel plow & Prairie dry & 30.35 & 39.28 & 24 \\
\hline PS & Row crop chisel plow & Prairie wet & na & 38.56 & 37 \\
\hline
\end{tabular}

Habitat classes as in Table 1, descriptions in Appendix A.

In the Production scenario, the area of habitat with high species richness decreased over much of Buck Creek watershed relative to the present, primarily from conversion of woodland, alfalfa/hay, pasture and Conservation Reserve Program set-aside to row crop (Table 2). Gains in habitat with high species richness in both watersheds were mostly from conversion of conventional- to conservation-till row crop. The Biodiversity and Water Quality scenarios supported higher species richness gains and lower species richness losses over more area relative to the present than the 
Table 3

Means and standard deviations of 1000 replicates of Monte Carlo estimates of median percent change in suitability-weighted habitat for selected groups of species. The first column shows the total number of species in each group ("Total Nspp"), followed by four sets of two columns that correspond to the three future landscapes and the past landscape. The first and second columns in each set are the mean and standard deviation, respectively, of the median percent change for the group

\begin{tabular}{|c|c|c|c|c|c|c|c|c|c|}
\hline Group & Total Nspp & Production & S.D. & Water quality & S.D. & Biodiversity & S.D. & Presettlement & S.D. \\
\hline \multicolumn{10}{|l|}{ Buck Creek } \\
\hline Amphibians & 12 & -3.2 & 0.3 & 64.6 & 6.0 & 24.2 & 12.9 & 27.0 & 7.6 \\
\hline Reptiles & 29 & -38.3 & 6.6 & 27.9 & 6.0 & -15.7 & 5.4 & 50.3 & 12.7 \\
\hline Birds & 146 & -40.9 & 3.6 & 20.7 & 3.5 & 90.7 & 11.2 & 35.3 & 9.3 \\
\hline Mammals & 52 & -3.0 & 5.2 & 17.1 & 4.8 & 41.5 & 7.5 & 47.8 & 9.2 \\
\hline Native Vert & 239 & -25.1 & 3.4 & 21.4 & 2.3 & 40.6 & 5.5 & 40.6 & 5.4 \\
\hline Introduced Vert & 8 & 20.8 & 27.6 & -14.5 & 10.7 & 1.3 & 12.4 & -52.6 & 13.0 \\
\hline $\mathrm{S} 1-\mathrm{S} 2$ & 24 & -56.4 & 1.6 & 39.9 & 8.8 & 15.8 & 11.7 & 37.1 & 19.3 \\
\hline Lepidoptera & 117 & -64.6 & 1.9 & 18.0 & 4.0 & -3.5 & 4.1 & 164.0 & 17.4 \\
\hline \multicolumn{10}{|l|}{ Walnut Creek } \\
\hline Amphibians & 12 & -1.2 & 0.2 & 181.3 & 21.7 & 1617.3 & 128.1 & 11529.3 & 1425.4 \\
\hline Reptiles & 29 & -36.6 & 8.1 & 54.9 & 19.0 & 36.5 & 11.4 & 131.1 & 31.3 \\
\hline Birds & 146 & -29.5 & 1.2 & 27.8 & 6.5 & 111.7 & 10.1 & -19.4 & 0.1 \\
\hline Mammals & 52 & 14.5 & 16.8 & 89.3 & 17.7 & 108.7 & 15.9 & 105.5 & 25.7 \\
\hline Native Vert & 239 & -16.8 & 6.7 & 42.9 & 6.2 & 98.9 & 7.2 & 33.8 & 9.6 \\
\hline Introduced Vert & 8 & 15.5 & 30.9 & 5.9 & 23.4 & 5.5 & 20.7 & -37.2 & 16.2 \\
\hline $\mathrm{S} 1-\mathrm{S} 2$ & 24 & -39.1 & 5.7 & 202.1 & 28.1 & 133.8 & 30.3 & 723.9 & 130.6 \\
\hline Lepidoptera & 117 & -41.6 & 0.9 & 116.8 & 11.7 & 123.2 & 9.4 & 1189.9 & 105.6 \\
\hline
\end{tabular}

Production scenario. In Buck Creek, the Biodiversity scenario resulted in more area with higher species richness gains. The conversion of conventional-till row crop, alfalfa/ hay, and Conservation Reserve Program lands to conservation-till and native-strip row crop resulted in an increase in species richness, as did the conversion of row crop in riparian areas to wet prairie and forest (Table 2). There were also some areas of species richness loss due to conversion of pasture to native strip row crop (Table 2). The Biodiversity scenario for Buck Creek showed a loss of species richness in some areas, because pasture, alfalfa/hay, and Conservation Reserve Program lands in the present were coded as suitable for more bird species (Tables 1 and 2) than savanna and dry native prairie. Savanna and dry prairie were the land cover restored in the reserve in the Biodiversity scenario. The greater number of animal species coded to pasture but not prairie was in part an artifact of splitting restored prairie into wet prairie and dry prairie classes in the species-habitat association matrix, whereas pasture was represented by a single class. In Walnut Creek watershed, the area of species richness gains was about the same in the Biodiversity and Water Quality scenarios, primarily due to conversion of conventional- to conservation-till row crop in the Water Quality scenario and to conservation-till and native-strip row crop in the Biodiversity scenario (Tables 1 and 2) although the resulting landscape configuration was quite different between scenarios.

\section{Discussion}

The development and evaluation of alternative future scenarios is one approach to engage people in a visioning process and to help quantify the ecological and socioeconomic impacts that could result from implementation of the alternatives (Nassauer et al., 2002; Steinitz et al., 2003). Comparison of presettlement landscapes to the present and alternative futures can help calibrate the impacts of future landscape change based on changes that have already occurred. The scenarios included in this study were intended to be a provocative but plausible basis for envisioning future directions for agricultural policy in the USA.

Further intensification of agriculture as envisioned in the Production scenario will lead to further decline of wildlife from loss of habitat in farmland, whereas alternative cropping and management practices, as envisioned in the Water Quality scenario or Biodiversity scenario would both benefit wildlife. Divergence in the effects of different scenarios was evident among taxa, particularly for reptiles as compared to other vertebrate taxa, and for butterflies as compared to most vertebrate taxa. Consideration of life history requirements of individual species or sets of species is thus necessary to provide information regarding those species most likely to be at risk from habitat loss as the landscape changes.

The modelling approach developed by White et al. (1997) has been quite flexible and robust in its applications (Hulse et al., 2000; Freemark and Olson, 2002; Santelmann et al., 2004). Model results were relatively robust across moderate uncertainty in habitat scores (Table 3). The modelling approach used in this study was responsive to changes in landscape composition but not landscape configuration. More complicated decision rules on what constitutes habitat can be incorporated when known (White et al., 1997; Hulse et al., 2000). The use of spatially-explicit population models run on the same future scenarios provides additional 
estimates of impacts on wildlife from landscape change (Rustigian et al., 2003; Clark and Danielson, Unpublished) that should be considered by decision makers and those developing agricultural policy.

The potential effects of global climate change on farmland should also be considered and potential ecological impacts investigated. Information on the nature of potential climate change, landforms, landscape structure, and dynamics of species' distributions across a hierarchy of spatial and temporal scales will need to be integrated (Kareiva et al., 1993). Comparative studies across landscape gradients, regions, or larger geographic areas will be particularly important for predicting the impacts of changes in landscape structure produced by global change and associated land-use change. For example, the possible effects of changes in the diversity within agricultural and forestry production systems on ecological complexity and function at the regional scale may be relevant. Agricultural and forestry production systems that are more diverse and complex may be not only more sustainable, but also more conducive to the migration of species among nature reserves, and hence lead to reduced rates of extinction as species cope with rapidly changing environmental regimes.

\section{Acknowledgements}

This research has been supported by a grant (NSF \#R8253335-01-0) from the Water/Watersheds of the U.S. Environmental Protection Agency's Science to Achieve Results (STAR) program. K. Freemark was supported under contract to Oregon State University. The statistical analyses described in this presentation have been funded in part by the U.S. Environmental Protection Agency through the STAR Cooperative Agreement CR82-9096-01 Program on Designs and Models for Aquatic Resource Surveys at Oregon State University. This paper has been subjected to the US EPA's peer and administrative review and approved for publication. Approval does not signify that the contents reflect the views of the Agency, nor does mention of trade names or commercial products constitute endorsement or recommendation for use.

\section{Appendix A. Descriptions of habitat classes}

\begin{tabular}{|c|c|c|c|}
\hline Class & Code & Name of land cover & Land cover description \\
\hline 1 & rc.cp & Row crops, chisel plow & $\begin{array}{l}\text { Row crops planted and cultivated using } \\
\text { conventional cropping methods }\end{array}$ \\
\hline 2 & rc.ct & Row crops, conservation till & $\begin{array}{l}\text { Row crops planted and cultivated using } \\
\text { conservation tillage and residue management }\end{array}$ \\
\hline 3 & rc.ns & $\begin{array}{l}\text { Strip intercropping with } \\
\text { native perennials }\end{array}$ & $\begin{array}{l}\text { Innovative agricultural practice in which strips } \\
\text { of corn and soybeans (rotated annually) are alternated with permanent strips of native perennial } \\
\text { grasses and forbs }\end{array}$ \\
\hline 4 & rc.sg & Small grains (e.g., oats) & Fields of small grains such as oats, barley etc. \\
\hline 5 & rc.fall & Row crop fallow (field skips) & $\begin{array}{l}\text { Field skips to which no fertilizer is applied, and which are not harvested but allowed to fallow with } \\
\text { some kind of herbaceous cover desired by farmer }\end{array}$ \\
\hline 6 & rc.os & Organic strip intercropping & Strip intercropping of organic corn and soybeans \\
\hline 7 & rc.o & Organic row crops & Organic corn and soybeans in large fields, not strip intercropping \\
\hline 8 & farmstead & Farmstead and urban & Farmsteads and small towns \\
\hline 9 & strip.h & Herbaceous strip cover & Grass waterways, fencerows, and other herbaceous cover found in narrow strips \\
\hline 10 & strip.w & Woody strip cover & Fencerows, shelterbelts and other cover planted in narrow strips \\
\hline 11 & grass.crp & Conservation reserve program & $\begin{array}{l}\text { Conservation reserve program; fields on highly erodible land that are planted to grass and forb } \\
\text { mixtures and set-aside, not cropped, grazed or mowed }\end{array}$ \\
\hline 12 & grass.hay & Alfalfa/hay & Alfalfa, hay, and other patches of mowed herbaceous cover \\
\hline 13 & grass.pd & Dry prairie & Patches of native tallgrass prairie in dryer upland areas \\
\hline 14 & grass.pw & Wet prairie & Patches of native wet prairie in wet lowland areas \\
\hline 15 & shrub.past & Pasture & Grazed herbaceous cover with occasional patches of shrubs, managed and seeded \\
\hline 16 & shrub.ung & Ungrazed shrubland & Patches of shrub-covered areas that are not grazed \\
\hline 17 & for.50 & Forest less than 50 years old & Ungrazed forest planted less than 50 years previously \\
\hline 18 & for.rug & Riparian forest ungrazed & Forested areas along streams and wetlands, ungrazed \\
\hline 19 & for.upug & Forested upland ungrazed & Forested areas in uplands, ungrazed \\
\hline 20 & for.upg & Forested upland grazed & Forested area in uplands that are grazed \\
\hline 21 & for.sug & Savanna ungrazed & Savanna areas that are ungrazed \\
\hline 22 & for.sg & Savanna grazed & Savanna areas that are grazed \\
\hline 23 & wet.sp & Semipermanent wetland & Prairie pothole wetlands that have water much of the year \\
\hline 24 & wet.pond & Farm ponds & Ponds on farmsteads \\
\hline 25 & wet.st & Streams & Streams \\
\hline 26 & wet.eng & Engineered wetlands & $\begin{array}{l}\text { Wetlands placed at outlet of tile drains or along roadsides to filter tile drainage water and } \\
\text { runoff from the road }\end{array}$ \\
\hline
\end{tabular}




\section{References}

Ahern, J., 1999. Spatial concepts, planning strategies and future scenarios: a framework method for integrating landscape ecology and landscape planning. In: Klopatek, J.M., Gardner, R.H. (Eds.), Landscape Ecological Analysis: Issues and Applications, 400. Springer, New York, pp. 175-201.

Baker, R.H., 1983. Michigan Mammals. Michigan State University Press, East Lansing, Michigan, 642 pp.

Baker, J., Hulse, D., Gregory, S., White, D., Van Sickle, J., Berger, P., Dole, D., Schumaker, N., 2004. Alternative futures for the Willamette River Basin, Oregon. Ecol. Appl. 14, 313-324.

Bergin, T.M., Best, L.B., Freemark, K.E., Koehler, K.J., 2000. Effects of landscape structure on nest predation in roadsides of a midwestern agroecosystem: a multiscale analysis. Landsc. Ecol. 15, 131-143.

Best, L.B., Bergin, T.M., Freemark, K.E., 2001. Influence of landscape composition on bird use of row crop fields. J. Wildl. Manage. 65 (3), 442-449.

Best, L.B., Freemark, K.E., Dinsmore, J.J., Camp, M., 1995. A review and synthesis of habitat use by breeding birds in agricultural landscapes of Iowa. Am. Midl. Nat. 134, 1-29.

Caire, W., Tyler, J.D., Glass, B.P., Mares, M.A., 1989. Mammals of Oklahoma. Oklahoma University Press, Norman Oklahoma, 567 pp.

Casper, G.S., 1996. Geographic Distributions of the Amphibians and Reptiles of Wisconsin. Milwaukeee Public Museum, Inc., Milwaukee, Wisconsin, 87 pp.

Christiansen, J.L., Bailey, R.M., 1991. The salamanders and frogs of Iowa. Nongame Technical Series No. 3. Iowa Department of Natural Resources, Des Moines, Iowa.

Clark, W.R., Young, R.E., 1986. Crop damage by small mammals in no-till cornfields. J. Soil Water Conserv. 338-341.

Coiner, C., Wu, J., Polasky, S., 2001. Economic and environmental implications of alternative landscape designs in the Walnut Creek watershed of Iowa. Ecol. Econ. 38, 119-139.

Collins, J.T., 1993. Amphibians and Reptiles in Kansas. The University of Kansas Museum of Natural History, Lawrence, Kansas, 283 pp.

Costanza, R., 2000. Visions of alternative (unpredictable) futures and their use in policy analysis. Conserv. Ecol. 4, 5 http.//www.consecol.org/vol4/ iss1/art5.

Freemark, K., 1995. Assessing effects of agriculture on terrestrial wildlife: developing a hierarchical approach for the US EPA. Landsc. Urban Plan. 31, 99-115.

Freemark, K., Dewar, H., Saltman, J., 1991. A Literature Review Of Bird Use Of Farmland Habitats In The Great Lakes, St. Lawrence Region. Technical Report Series No. 114. Canadian Wildlife Service, HQ, Environment Canada, Hull, Que., 214 pp.

Freemark, K.E., Olson, D., 2002. Integrated Landscape Planning and Assessment for the South Okanagan Region, BC. CD of unpublished CWS contract reports, Ottawa, ON.

Galatowitsch, S., van der Valk, A., 1994. Restoring Prairie Wetlands: An Ecological Approach. Iowa State University Press, Ames, Iowa, $246 \mathrm{pp}$.

Harding, J.H., 1997. Amphibians and Reptiles of the Great Lakes Region. University of Michigan Press, Ann Arbor, Michigan, 378 pp.

Hayslett, L.A., Danielson, B.J., 1994. Small mammal diversity and abundances in three central Iowa grassland habitat types. Prairie Naturalist 26, 37-44.

Hewes, L., 1951. The northern wet prairie of the United States: nature, sources of information, and extent. Ann. Assoc. Am. Geogr. 41, 307323.

Hulse, D.W., Eilers, J., Freemark, K.E., Hummon, C., White, D., 2000. Planning alternative future landscapes in Oregon: evaluating effects on water quality and wildlife habitat. Landsc. J. 19, 1-19.

Jackson, L.S., Thompson, C.A., Dinsmore, J.J., 1996. The Iowa Breeding Bird Atlas. University of Iowa Press, Iowa City, Iowa, 484 pp.
Kareiva, P.M., Kingsolver, J.G., Huey, R.B., 1993. Biotic Interactions and Global Change. Sinauer Associates Inc., Sunderland, Massachusetts, 559 pp.

Kent, T.H., Dinsmore, J.J., 1986. Birds in Iowa. Iowa City, Iowa, 391 pp.

Krebs, J.R., Wilson, J.D., Bradbury, R.B., Siriwardena, G.M., 1999. The second silent spring? Nature 400, 611-612.

Kurta, A., 1995. Mammals of the Great Lakes Region, Revised ed. University of Michigan Press, Ann Arbor, Michigan, 376 pp.

Lokemoen, J.T., Beiser, J.A., 1997. Bird use and nesting in conventional, minimum-tillage, and organic cropland. J. Wildl. Manage. 61, 644655.

Meadows, D., 1996. Envisioning a sustainable world. In: Costanza, R., Segura, O., Martinez-Alier, J. (Eds.), Getting Down to Earth: Practical Applications of Ecological Economics. Island Press, Washington, DC, 117-126, $274 \mathrm{pp}$.

Minton Jr., S.A., 1972. Amphibians and Reptiles of Indiana. Indiana Academy of Science, Indianapolis, Indiana, 346 pp.

Nassauer, J.I., Corry, R.C., 2004. Using normative scenarios in landscape ecology. Landsc. Ecol. 19, 343-356.

Nassauer, J.I., Corry, R.C., Cruse, R.M., 2002. Alternative future landscape scenarios: a means to consider agricultural policy. J. Soil Water Conserv. 57, 44-53.

Oldfield, B., Moriarty, J.J., 1994. Amphibians and Reptiles Native to Minnesota. University of Minnesota Press, Minneapolis, Minnesota, 237 pp.

Pratt, J.R., Cairns Jr., J., 1992. Ecological risks associated with the extinction of species. In: Cairns, Jr., J., Neiderlehner, B.R., Orvos, D.R. (Eds.), Predicting Ecosystem Risk. Advances in Modern Environmental Toxicology. Princeton Scientific Publishing Co., Inc., Princeton, NJ, p. 347.

Prior, J., 1991. Landforms of Iowa. University of Iowa Press, Iowa City, Iowa, $153 \mathrm{pp}$.

Runge, C.F., 1997. Environmental protection from farm to market. In: Chernow, M.R., Esty, D.C. (Eds.), Thinking Ecologically: The Next Generation of Environmental Policy. Yale University Press, New Haven and London, pp. 200-216, 271.

Rustigian, H., Santelmann, M., Schumaker, N., 2003. Assessing the potential impacts of alternative landscape designs on amphibian population dynamics. Landsc. Ecol. 18, 65-81.

Santelmann, M., Freemark, K., White, D., Nassauer, J., Clark, M., Danielson, B., Eilers, J., Cruse, R., Galatowitsch, S., Polasky, S., Vaché, K., $\mathrm{Wu}$, J., 2001. Applying ecological principles to land-use decision making in agricultural watersheds. In: Dale, V.H., Haeuber, R. (Eds.), Applying Ecological Principles to Land Management. Springer-Verlag, NY, 346 pp.

Santelmann, M., White, D., Freemark, K., Nassauer, J., Eilers, J., Vache, K., Danielson, B., Corry, R., Clark, M.E., Polasky, S., Cruse, R.M., Sifneos, J., Rustigian, H., Coiner, C., Wu, J., Debinski, D., 2004. Assessing alternative futures for agriculture in the US Corn Belt. Landsc. Ecol. 18, $1-18$.

Schwartz, C.W., Schwartz, E.R., 1981. The Wild Mammals of Missouri, Rev. Ed. University of Missouri Press and Missouri Department of Conservation, Columbia, Missouri, 356 pp.

Scott, J.A., 1986. The Butterflies of North America: A Natural History and Field Guide. Stanford University Press, Stanford, CA, USA, 583 pp.

Smith, P.W., 1961. The amphibians and reptiles of Illinois. Illinois Natural History Survey Bulletin 28, 1-298.

Snyder, E.J., Best, L.B., 1988. Dynamics of habitat use by small mammals in prairie communities. Am. Midl. Nat. 119, 128-136.

Stallman, H.R., Best, L.B., 1996. Small-mammal use of an experimental strip intercropping system in Northeastern Iowa. Am. Midl. Nat. 135, 266-273.

Steinitz, C., Arias, H., Bassett, S., Flaxman, M., Goode, T., Maddock III, T., Mouat, D., Peiser, R., Shearer, A., 2003. Alternative Futures for Changing Landscapes: The Upper San Pedro River Basin in Arizona and Sonora. Island Press, Washington, DC, 202 pp. 
Tilman, D., Fargione, J., Wolff, B., D’ Antonio, C., Dobson, A., Howarth, R., Schindler, D., Schlesinger, W.H., Simberloff, D., Swackhamer, D., 2001. Forecasting agriculturally driven global environmental change. Science 292, 281-284.

Vaché, K., Eilers, J., Santelmann, M., 2002. Water quality modeling of alternative agricultural scenarios in the US Corn Belt. JAWRA 38, 773787.

Vogt, R.C., 1981. Natural History of Amphibians and Reptiles in Wisconsin. Milwaukee Public Museum, Milwaukee, Wisconsin, 205 pp.
White, D., Minotti, P.G., Barczak, M.J., Sifneos, J.C., Freemark, K.E., Santelmann, M.V., Steinitz, C.F., Kiester, A.R., Preston, E.M., 1997. Assessing risks to wildlife habitat from future landscape change. Conserv. Biol. 11, 349-360.

White, D., Preston, E.M., Freemark, K.E., Kiester, A.R., 1999. A hierarchical framework for conserving biodiversity. In: Klopatek, J.M., Gardner, R.H. (Eds.), Landscape Ecological Analysis: Issues and Applications. Springer, New York, pp. 127153. 